\title{
Heidi Hansen 2011. Kommunikation skaber din organisation. København: Hans Reit- zels Forlag. 333 sider. ISBN 978-87-412-5420-3
}

I Kommunikation skaber din organisation tager Heidi Hansen fat på en række aspekter af organisationskommunikation, der "dækker over mange forskellige kommunikative discipliner som eksempelvis intern kommunikation, krisekommunikation, værdikommunikation, storytelling og public relations" (s. 13). De berørte aspekter spænder bredt fra eksempelvis kultur (kapitel 4) og værdier (kapitel 5) til kanaler (kapitel 9), genrer (kaptitel 10), kommunikationspolitik (kapitel 12) og måling af kommunikation (kapitel 13).

Bogen, der henvender sig til studerende på videregående uddannelser og praktikere, tager udgangspunkt i den såkaldte kommunikationstrekant, hvilken afspejler forfatterens to centrale præmisser: semiotik og socialkonstruktivisme. Kommunikationstrekanten, der introduceres i kapitel 3, repræsenterer en holistisk tilgang til organisationskommunikation bestående af etos (omverdenens afkodning eller fortolkning af virksomheden), identitet (det, virksomheden faktisk er) og imageønske (det, virksomheden siger om sig selv). Modellen, der er inspireret af den semiotiske trekant (nærmere bestemt Pierces tredelte tegnforståelse), understreger, at det er samspillet mellem disse tre elementer, der er i fokus. I tilgift til det semiotiske og socialkonstruktivistiske afsæt, er bogens fokus på værktøjer frem for opskrifter (s. 9). Sigtet er dermed ikke at give målgrupperne en række færdige løsninger, men at sætte dem i stand til selv at løse forskellige kommunikationsudfordringer i organisationer (s. 22).

Forfatteren berører mange aspekter, og bogens styrke er, at den kommer bredt omkring begreber, forståelse og værktøjer anvendt i organisationskommunikation. Samtidig er dette også bogens svaghed. Forfatteren påpeger i forordet, at der er aspekter, bogen ikke når omkring (s. 9), men alligevel er bogens bredde et problem: Den vil for meget. I tilgift til centrale aspekter, der hver har særskilte kapitler eksempelvis kultur og værdier, kommer forfatteren omkring CSR (nævnes kapitel 5 om værdier), appreciative inquiry (knyttes til narrative organisationsforståelse i kapitel 6), autopoiese (omtales i kapitel $14 \mathrm{i}$ forbindelse med autokommunikation) samt en lang række andre begreber og teoriområder. Den kritiske læser undrer sig over, hvordan disse aspekter er udvalgt. Forfatteren forklarer bogens valg i forordet med henvisning til "hvad jeg synes, der er rigtigt godt at vide om organisationskommunikation, hvis man kun læser én bog om emnet" (s. 10). Det bliver dog ikke gjort klar for læseren, hvorfor de behandlede aspekter er rigtig gode. Forfatteren foretager således en lang række valg uden at begrunde eller forklare disse. Derudover er det uklart, hvilke værktøjer, der behandles. Dette ansporer læseren til at spørge: Hvad er det for nogle værktøjer, bogen beskæftiger sig med? Hvad er et værktøj i en organisationskommunikativ optik? Er eksempelvis kultur (kapitel 4), kommunikationspolitik (kapitel 12) og autokommunikation (kapitel 14) værktøjer? Eller indeholder de en række værktøjer hver især? Og hvorfor er disse værktøjer vigtige, når der skal løses kommunikationsopgaver i en organisation?

De manglende forklaringer og begrundelser bevirker desuden, at bogen savner en klar sammenhæng mellem de mange begreber og værktøjer. Dette hænger måske sammen med, at bogens formål synes uklart. Ambitionen er, ifølge forfatteren, "at skabe en grundlæggende forståelse af organisationskommunikation og de udfordringer, vi står over for her" (s. 22). Men den grundlæggende forståelse (kommunikationstrekanten) overføres ikke entydigt til de efterfølgende kapitler (4 til 14). Kommunikationstrekanten optræder kun lejlighedsvis i bogens øvrige kapitler (eksempelvis 4 og 5), og bliver dermed ikke brugt i tilstrækkelig grad som en samlende, forklarende ramme eller værktøjskasse. Det undrer eksempelvis, at modellen ikke sættes i relation til de øvrige kommunikationsmodeller, der inddrages i kapital 7. Derudover savner læseren en kobling mellem trekantens iboende forståelse af organisationskommunikation og konkrete aspekter som valg af kanaler (kapitel 9), betydning af genrer (kapitel 11), mulige retoriske strategier (kapitel 11) og udformning af kommunikationspolitik (kapitel 12). Da sammenhængen ikke ekspliciteres, åbnes op 
for en række spørgsmål så som: Hvorfor opstille en kommunikationsmodel i kapitel 3 for derefter at gennemgå yderligere kommunikationsmodeller i kapitel 7? Hvorfor ikke behandle de forskellige kommunikationsmodeller som en del af det at opstille bogens egen kommunikationsmodel? Og hvis organisationskommunikation dækker over mange forskellige discipliner herunder intern kommunikation, krisekommunikation og public relations (s. 13), hvorfor er det så kun intern kommunikation, der får sit eget kapitel (kapitel 8)? Hvorfor ikke (også) inkluderer kapitler om krisekommunikation og public relations?

Andre spørgsmål knytter sig til den socialkonstruktivistiske præmis, som forfatteren anlægger som udgangspunkt for sin tilgang til organisationskommunikation. Med udgangspunkt i en socialkonstruktivistisk tanke er bogens centrale pointe, som angivet i titlen, at kommunikation skaber en organisation. Dette behandles eksplicit i bogens kapitel 6, hvor fokus er på en narrative forståelse af organisation, og i kapitel 8, hvor omdrejningspunktet er intern kommunikation. Det undrer imidlertid, at den tanke, at kommunikation konstituerer en organisation tilsyneladende ikke også omfatter kommunikation fra, til og om organisationen dvs. ekstern kommunikation. Således skelner forfatteren tilsyneladende mellem to forskellige kommunikationsparadigmer i forhold til intern og ekstern kommunikation reflekteret i forskellige syn på interne og eksterne interessenter. Mens interne interessenter, medarbejderne, opfattes som medkonstruerende, medfortolkende og medfortællende (interaktionsparadigme), ses eksterne interessenter som en passiv målgruppe, der skal tales til (transmissionsparadigme). Omverdenen er et spejl for organisationens identitetskonstruktion. Det dobbelttydige forhold til socialkonstruktivismen ses således også i bogens tilgang til identitet, der defineres som "det, organisationen i virkeligheden er" (s. 41): En essentialistisk forståelse, der efterfølgende nuanceres i forhold til en konstruktivistisk tanke, men alligevel fremhæves i kommunikationstrekanten (hvor identitet sidestilles med "det, virksomheden faktisk er"). Hermed italesættes identitet ikke som et socialt konstrueret fænomen. Det samme gør sig gældende for bogens gennemgang af kultur (kapitel 4) og værdier (kapitel 5). Således er der vaklen at spore, når det kommer til det socialkonstruktivistiske verdenssyn. Dette anlægges på organisationskommunikation, men ikke på de emner, der i øvrigt behandles. At bogen behandler eksempelvis identitet som både socialt konstrueret og essentiel understreger kompleksiteten og nuancerne i begrebet. Dette er en styrke ved en grundbog, men hvorfor så anlægge et socialkonstruktivistisk perspektiv i udgangspunktet? Hvorfor ikke arbejde med de forskellige perspektiver og nuancerne mellem disse?

Bogen er generelt velskrevet og velformidlet. Dog er brugen er 'vi' til tider forstyrrende. Det anvendes i forskellige kontekster og inkluderer forskellige kollektiver, uden at disse introduceres nærmere som eksempelvis: "Når vi skal svare på en forespørgsel eller en klage, kommunikerer vi ikke først i det øjeblik, vi sender et svar af sted. Den tid, kunden venter på svar, kommunikerer også noget om vores identitet. Medarbejdernes adfærd, deres kropssprog og omgangstone er også kommunikation. Vi kan ikke ikke-kommunikere.” (s. 41) Det er således op til læseren at afkode, om det enkelte "vi" er en reference til mennesker, kommunikationspraktikere, medarbejdere i en organisation, organisationen som sådan eller noget femte.

Sammenfattende kan det siges, at forfatteren har meget godt på hjerte, og introducerer bredt til organisationskommunikationens mange facetter, men at det gode ofte drukner i manglende fokus og forklaring. De mange forskellige facetter efterlader et forvirret indtryk hos læseren. Som nævnt, skriver forfatteren i forordet, at bogen gerne skal være fyldestgørende, "hvis man kun læser én bog om emnet". Men overblikket forsvinder i bestræbelserne på at realisere dette, og bogen stiller flere spørgsmål, end den giver svar. Som potentiel værktøjskasse til praktikere er bredden fornuftigt, selv om der mangler en klar skelnen og kobling mellem tilgang, begreber og værktøjer. I forhold til studerende savner bogen ydermere struktur og sammenhæng samt argumentation og begrundelser for til- og fravalg.

Trine Susanne Johansen Aarhus Universitet 